\title{
ETOS WSPÓŁCZESNEGO NAUCZYCIELA W OPINII NAUCZYCIELI I RODZICÓW
}

Streszczenie: Zagadnienie etosu nauczycielskiego jest nadal bardzo ważną kwestią niemogącą zejść na dalszy plan procesu kształcenia i wychowania. Nawet jeśli pojęcie etosu słyszane jest coraz rzadziej i kojarzy się raczej z dawną literaturą piękną, nie oznacza to, że etos nie istnieje. Sam termin bywa zastępowany innymi określeniami, ale znajduje swoje miejsce w literaturze i praktyce edukacyjnej tak, jak bezdyskusyjna i niezmiennie obecna jest wychowawcza rola szkoły.

Słowa kluczowe: etos, etyka zawodu nauczyciela, nauczyciel, profesja nauczycielska, wychowanie

\section{Wprowadzenie}

Wykształcenie i praktyka zawodowa, chociaż stanowią istotne czynniki przygotowujące do zawodu, nie gwarantują dobrej jakości pracy czy satysfakcji z wykonywanego zawodu. Każdy z wymienionych elementów jest również zbyt wąską kategorią, by scharakteryzować konkretnego nauczyciela. W niniejszym artykule podjęto refleksję w oparciu o badania nad etosem nauczycielskim, uznając, iż rozważanie tego właśnie zagadnienia pozwoli na wyjaśnienie obszarów pracy nauczycielskiej trudnych do uchwycenia za pomocą innych kategorii pojęciowych.

\section{Etos w literaturze przedmiotu}

Kwerenda literatury naukowej pozwala stwierdzić, że wielokrotnie podejmowano próby zdefiniowania pojęcia etosu. Jest ono różnie wyjaśniane, jednak definicje mają wiele wspólnych elementów. Autorzy są zgodni co do tego, iż etos jest cechą charakterystyczną grup społecznych. Kluczowe miejsce w jego obrębie zajmują wartości będące swoistym spoiwem zbiorowości. Etos jest związany z hierarchią wartości, ale obejmuje swym zasięgiem dużo większy obszar aktywności ludzi zaangażowanych w jedną, wspólną aktywność (pracę, rodzinę, religię, zainteresowania etc.). Nie jest tylko moralnością określonej grupy społecznej $^{1}$. Maria Ossowska sytuuje wyjaśnienie pojęcia etosu w obrębie zagadnień związanych ze stylem życia (Ossowska 1956, s. 24). Podobnie dla Andrzeja Sicińskiego konkretne,

1 Według Maxa Schelera: „«Moralność» jest systemem reguł wyboru preferowanych wartości wymagającym dopiero odkrycia za konkretnymi ocenami danej epoki i danego ludu jako jego «konstytucja moralna» 
nieprzypadkowe zachowania człowieka tworzą określony styl życia (Siciński 1976, s.17). Ich podporządkowanie wspólnym celom i wartościom sprawia, że zachowania członków zbiorowości spełniają funkcje wyróżniające poszczególne grupy społeczne.

Styl życia jest związany również z trybem życia stanowiącym sposób organizacji czasu czy biegu życia oraz jego poziomem. Obydwie kategorie wydają się istotnie związane z funkcjonowaniem jednostki, podczas gdy etos dotyczy grup społecznych. Istnieje jednak silne powiązanie pomiędzy stylem życia pojedynczego człowieka i grupą społeczną, do której należy. Właśnie od siły tego powiązania zależy realizacja etosu grupowego oraz jego trwałość.

Niemniej istotnym czynnikiem związanym z etosem jest jakość życia rozumiana jako różnica pomiędzy wartościami pożądanymi i rzeczywiście posiadanymi (Czapiński, Panek 2009, s. 13). Dotyczy ona czynników ekonomicznych, ale i wartości niezwiązanych ze sferą finansową, takich jak rodzina, uczestnictwo w kulturze czy innych elementów zapewniających poczucie dobrostanu.

Styl życia będący ważnym elementem etosu grupowego może rodzić pytania dotyczące poziomu dobrowolności, a może nawet wolności członków grup etosowych. Poziom samodzielności wyboru, a więc i osobistego wkładu w działania grupy, zależy także od cech osobowych jej członków. Wybór określonej społeczności wskazuje na konkretne cechy człowieka, kształtuje również jego biografię. Tego typu obustronność wpływu wyjaśnia częściowo naturę relacji jednostka - grupa społeczna i prowadzi do kolejnego pojęcia, z jakim autorzy utożsamiają etos. Chodzi o "całokształt elementów dorobku społecznego" (Czarnowski 1958, s. 12), a więc wspólne ludziom wartości. Nie pozostają one jednak wyłącznie w sferze abstrakcyjnej. Dorobek społeczny stanowią mniej lub bardziej konkretne wytwory pojawiające się z określoną regularnością. Mogą to być również dobra mające związek z kultem, obyczajem, prawem czy edukacją, pośród których ważne miejsce zajmuje język. Jest on niewątpliwie niezbędnym narzędziem życia i rozwoju społeczeństw, spełnia istotną rolę przy tworzeniu się i funkcjonowaniu grup społecznych.

Etos jest również postrzegany jako „mechanizm warunkujący zachowania” (Klepajczuk 1995, s. 8) czy „postawa człowieka” (Znamierowski 1964, s. 86). W świetle tego typu definicji komponenty emocjonalne, poznawcze i behawioralne odnoszące się do jednostki ludzkiej warunkują etos grupy społecznej, do której człowiek przynależy. Oznacza to, iż etos wywiera wpływ na najistotniejsze dziedziny życia członka grupy etosowej.

W swoich rozważaniach Jan Legowicz posunął się jeszcze dalej nazywając etos „możnością, pedagogiczna potrzebą wewnętrzną, aktywnym nawykiem” (Legowicz 1984, s. 274). Takie ujęcie jest dalekie od czysto teoretycznego podejścia, wskazuje na ogromne zaangażowanie emocjonalne nauczyciela. Etos swojej grupy zawodowej traktuje on nie tylko jako powinność, ale czyni zeń potrzebę własnej egzystencji nauczyciela.

Próby zdefiniowania etosu za pomocą pojęcia „wzoru osobowego" (Meibaum 1979, s. 127) również zakładają osobiste przejęcie się wartościami, ale z silnie występującym komponentem decyzyjnym uzależnionym od osobistej wolności człowieka. Wzór osobowy w grupie etosowej staje się przedmiotem aspiracji jej członków, typem idealnym i tylko od

i zdolnym przebyć ewolucję, która nie ma nic wspólnego ze wzrostem dopasowania ocen i działania pod władzą jakiejś danej moralności do zmiennej rzeczywistości życia” (Scheler 2008, s. 68). 
członków zbiorowości i ich zaangażowania zależy, czy etos nie stanie się jedynie niezbyt poważnie traktowaną utopijną figurą.

\section{Cel i organizacja badań}

Badania opisane w tym miejscu miały na celu ukazanie, co sądzą na temat etosu i zmiany w jego obrębie nauczyciele i rodzice. Istotny dla badacza był również stosunek respondentów do tego zjawiska. Wydaje się, iż społeczne zapotrzebowanie na wszystko to, co dawniej wiązało się z etosem, jest nadal obecne, zmienił się tylko status pojęcia lub sam termin etos został zastąpiony innym. Być może wymagania względem nauczycieli kiedyś traktowane w kategoriach powinności moralnych obecnie okażą się w większej mierze odnosić do nauczycielskiego profesjonalizmu rozumianego jako zespół określonych umiejętności ${ }^{2}$.

Badania zostały przeprowadzone w 2014 roku w placówkach przedszkolnych i szkolnych w Polsce. Respondenci to losowo wybrani nauczyciele oraz rodzice uczniów. Przebadano 132 nauczycieli pracujących w obydwu typach instytucji edukacyjnych. Sześćdziesiąt procent uczestniczących w badaniu nauczycieli (79 osób) to pracownicy szkół podstawowych, pozostałe 40\% (53 osoby) pracuje w przedszkolach. Rodzice, którzy wypełniali ankiety (123 respondentów) mają dzieci w wieku przedszkolnym lub szkolnym. Rodzice przedszkolni stanowią $43 \%$ respondentów tej grupy ( 53 osoby), rodzice dzieci w wieku szkolnym to $57 \%$ badanych (70 osób).

Jeśli chodzi o narzędzia badawcze, zastosowano kwestionariusz ankiety własnej konstrukcji. Dokonano analizy ilościowej. Obliczenia statystyczne przeprowadzono przy pomocy oprogramowania STATISTICA 10 PL. W przeprowadzonych testach statystycznych przyjmowano standardowy pięcioprocentowy $(\alpha=0,05)$ poziom istotności statystycznej.

Do zbadania istotności statystycznej związku kolejnych zmiennych zależnych z dwiema zmiennymi niezależnymi głównymi, tj. usytuowanie roli względem dziecka (nauczyciele versus rodzice), oraz typu instytucji edukacyjnej (przedszkole versus szkoła podstawowa), wykorzystano analizę logarytmiczno-liniową. Wykorzystanie analizy logarytmiczno-liniowej umożliwiło ocenę istotności statystycznej zarówno zmiennych niezależnych rozpatrywanych osobno (efekty główne), jak i jednoczesnego wpływu obydwu zmiennych niezależnych głównych (efekt interakcji). W przypadku pierwszego efektu głównego, tj. usytuowania roli względem dziecka, zestawiano ze sobą odpowiedzi nauczycieli i rodziców. Efekt główny typu instytucji edukacyjnej opierał się na porównaniach pomiędzy przedstawicielami szkół podstawowych (nauczyciele szkół podstawowych i rodzice uczniów szkół podstawowych) z przedstawicielami przedszkoli (nauczyciele przedszkoli i rodzice dzieci w wieku przedszkolnym). W przypadku efektu interakcji porównywano ze sobą cztery podgrupy - nauczycieli szkół podstawowych, nauczycieli w przedszkolach, rodziców uczniów szkół podstawowych i rodziców dzieci w wieku przedszkolnym.

Związek zmiennych zależnych ze zmienną niezależną szczegółową wieku został poddany weryfikacji również przy wykorzystaniu analizy log-liniowej. Badaniu podlegała

2 Najbardziej rozpowszechnione znaczenie profesjonalizacji odnosi się do „dążenia grupy zawodowej do osiągnięcia cech charakteryzujących tak zwaną "pełną profesję», co wiąże się z podwyższeniem pozycji zawodu" (Lalak, Pilch 1999, s. 214). 
istotność statystyczna dwóch efektów - efektu głównego wieku oraz efektu interakcji wieku i usytuowania roli względem ucznia. Efekt główny wieku zbadano poprzez porównania pomiędzy osobami w okresie rozwojowym wczesnej dorosłości (<35 lat) z osobami w okresie średniej dorosłości (35-64 lata). W przypadku efektu interakcji, dokonywano porównań pomiędzy czterema podgrupami uczestników badania - rodzicami w okresie wczesnej i średniej dorosłości oraz nauczycielami będącymi w analogicznym wieku.

Dokonano również porównań ze względu na zmienną niezależną szczegółową p ł c i. Z uwagi na to, że mężczyźni stanowią jedynie 13\% wszystkich uczestników badania, niemożliwe było w tym przypadku przeprowadzenie analizy wielozmiennowej. Dlatego do pomiaru istotności statystycznej związku pomiędzy kolejnymi zmiennymi zależnymi a płcią wykorzystywano test chi-kwadrat niezależności. W przypadku dwóch zmiennych zależnych mierzonych na skalach porządkowych (p5 i p6), do przeprowadzenia porównań międzygrupowych, wykorzystywano test nieparametryczny $U$ Manna-Whitnyea.

Zbadanie wpływu ostatniej zmiennej niezależnej szczegółowej - w y k s z t a ł c e n i a, nie zostało przeprowadzone. Niemal 95\% uczestników badania legitymowało się wykształceniem wyższym, w związku z czym przeprowadzenie testów statystycznych nie miało uzasadnienia merytorycznego.

\section{Wiedza na temat etosu}

Badanie rozpoczęto od zapytania respondentów, czy zetknęli się kiedykolwiek z pojęciem e t o s u. W przebadanej próbie wszyscy nauczyciele szkolni i $96 \%$ nauczycieli przedszkolnych spotkało się z tym terminem, 96\% rodziców dzieci szkolnych i 93\% rodziców dzieci przedszkolnych zna pojęcie etosu. Jedynie niewielki odsetek rodziców i nauczycieli nie słyszał nigdy o etosie. Rysunek 1 przedstawia rozkład wyników w zależności od usytuowania roli względem dziecka oraz typu instytucji edukacyjnej.

Rysunek 1. Rozkład odpowiedzi na pytanie o znajomość terminu etos 


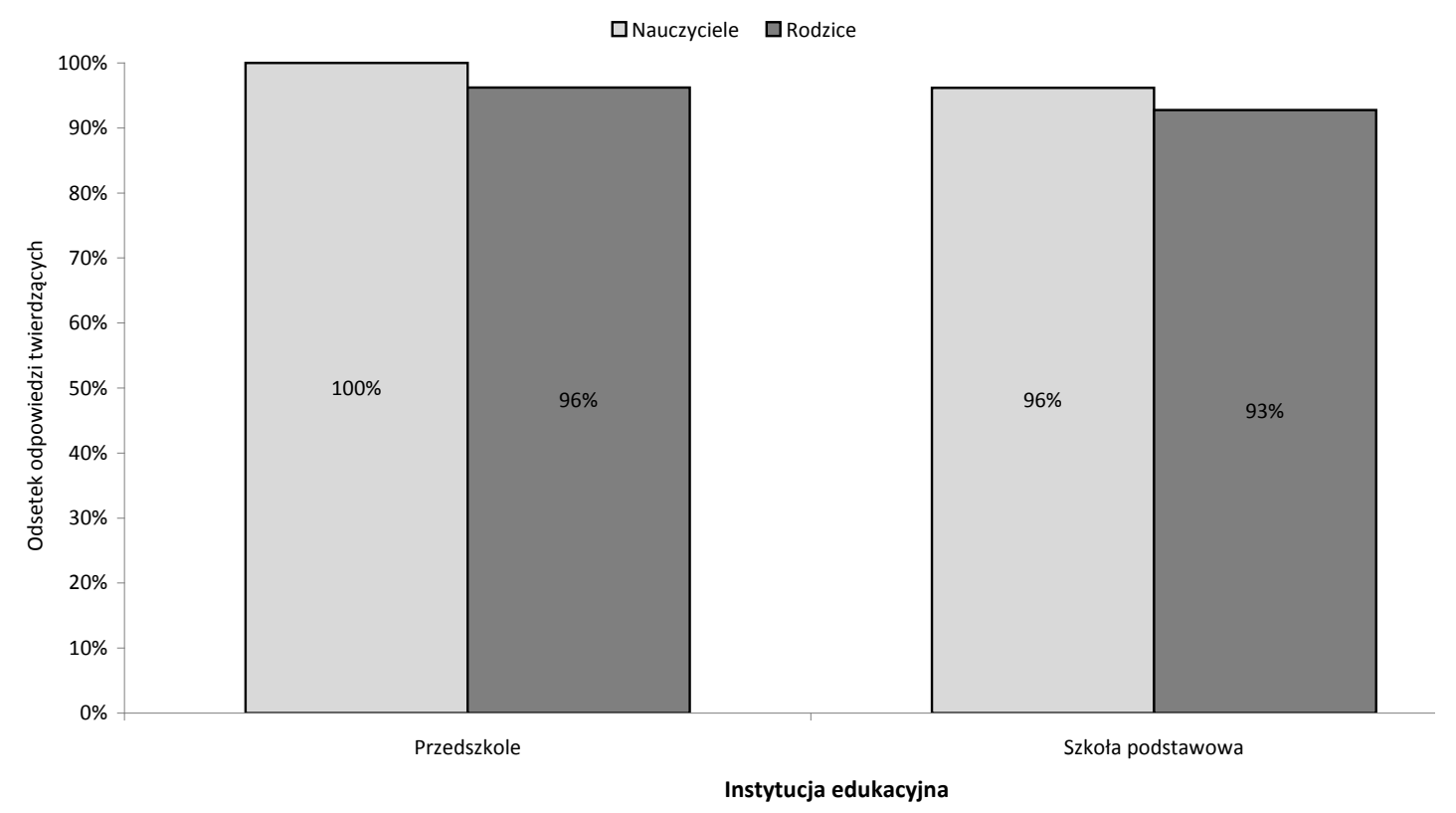

źródło: opracowanie własne

W celu sprawdzenia, czy odpowiedzi ankietowanych różnią w sposób istotny statystycznie w zależności od roli pełnionej względem ucznia oraz typu instytucji edukacyjnej, przy pomocy analizy log-liniowej przeprowadzono testy współzależności (tabela 1). Uzyskane wyniki wskazują na to, że odsetki osób, które spotkały się z terminem etos są w poszczególnych podgrupach zbliżone do siebie.

Tabela 1. Związek usytuowania roli oraz typu instytucji edukacyjnej i percepcji terminu etos - wyniki analizy log-linowej

\begin{tabular}{lllll}
\hline Zmienne niezależne & $N$ & $D f$ & $\chi^{2}$ & $p$ \\
\hline Usytuowanie roli & 252 & 1 & 1,82 & 0,177 \\
Typ instytucji & 252 & 1 & 1,67 & 0,196 \\
Usytuowanie roli * typ instytucji & 252 & 1 & 0,40 & 0,525 \\
\hline
\end{tabular}

źródło: opracowanie własne

Należało się spodziewać, iż wiedza na temat terminu etos będzie zróżnicowana u badanych w różnym wieku. Wydawać się mogło, iż pojęcie to jest lepiej znane grupie starszych respondentów, a liczba młodszych ankietowanych, którzy spotkali się z tym terminem będzie niższa. Problem etosu nauczycielskiego pojawiał się w dawnej literaturze pięknej. Był to temat poruszany w książkach wchodzących w skład kanonu lektur szkolnych. Można wymienić w tym miejscu tytuły, takie jak: $A B C$ Elizy Orzeszkowej, Lalka Bolesława Prusa, Siłaczka Stefana Żeromskiego czy Kamienie na szaniec Aleksandra Kamińskiego, czytane w szkole przez pokolenia młodzieży. Obecnie lektury dla uczniów, szczególnie w szkole podstawowej, są dobierane przez samych nauczycieli. Które pozycje wydawnicze zostaną wybrane zależy w dużej mierze od tego, jakie są zainteresowania, teorie osobiste na temat 
edukacji oraz wartości, jakimi kieruje się nauczyciel. Ponadto wydaje się, iż zagadnienia powiązane z problematyką etyczną nie zajmują najwyższych pozycji wśród zainteresowań współczesnych młodych ludzi. Kwestie dotyczące moralności nie są również najistotniejszymi elementami ponowoczesnego stylu życia, który na dzień dzisiejszy reprezentuje już nie tylko młodzież, ale także jej rodzice. Stąd można było domniemywać, iż wyniki w dwóch grupach wiekowych (wczesna dorosłość i średnia dorosłość) będą się różnić, jednak badania tego nie potwierdziły.

Następnie zapytano respondentów o to, z czym jest związany etos. Było to pytanie typu zamkniętego. Ankietowani mogli dokonać wielokrotnego wyboru spośród trzech zaproponowanych odpowiedzi. Najczęściej wskazywano na związek etosu z życiem zawodowym ( $87 \%$ odpowiedzi) oraz z życiem osobistym ( $69 \%$ odpowiedzi). Zależność etosu i czasu wolnego to $34 \%$ wyborów (rysunek 2).

Jak pokazuje wykres (rysunek 2), respondenci kojarzą etos głównie z życiem zawodowym. Można wnioskować, iż ma to pewien związek z doświadczeniami związanymi z literaturą, ale i doniesieniami medialnymi. Bohaterowie książek omawianych w szkole poświęcali życie dla swoich uczniów czy też pacjentów i byli stawiani za wzór do naśladowania. Również w powszechnej opinii wysokie wymagania etyczne stawia się głównie wobec zawodów związanych z bezpośrednią służbą drugiemu człowiekowi (lekarze, nauczyciele). Druga najczęściej wybierana odpowiedź dotyczyła życia osobistego. Wysokie wymagania społeczne względem niektórych profesji dotyczą nie tylko sfery zawodowej, ale również życia osobistego tejże grupy społecznej. Innymi słowy: nauczyciel czy lekarz może wykonywać swoją pracę na wysokim poziomie profesjonalizmu jedynie wówczas, gdy również jego życie osobiste jest bez zarzutu w sferze etycznej. Można domniemywać, iż wyniki te są związane ze szkolnymi doświadczeniami respondentów oraz powszechną opinią kształtowaną przez media i najbliższe otoczenie biorące udział w wychowaniu młodego człowieka.

Rysunek 2. Rozkład odpowiedzi na pytanie: „Z czym jest związany etos?” 


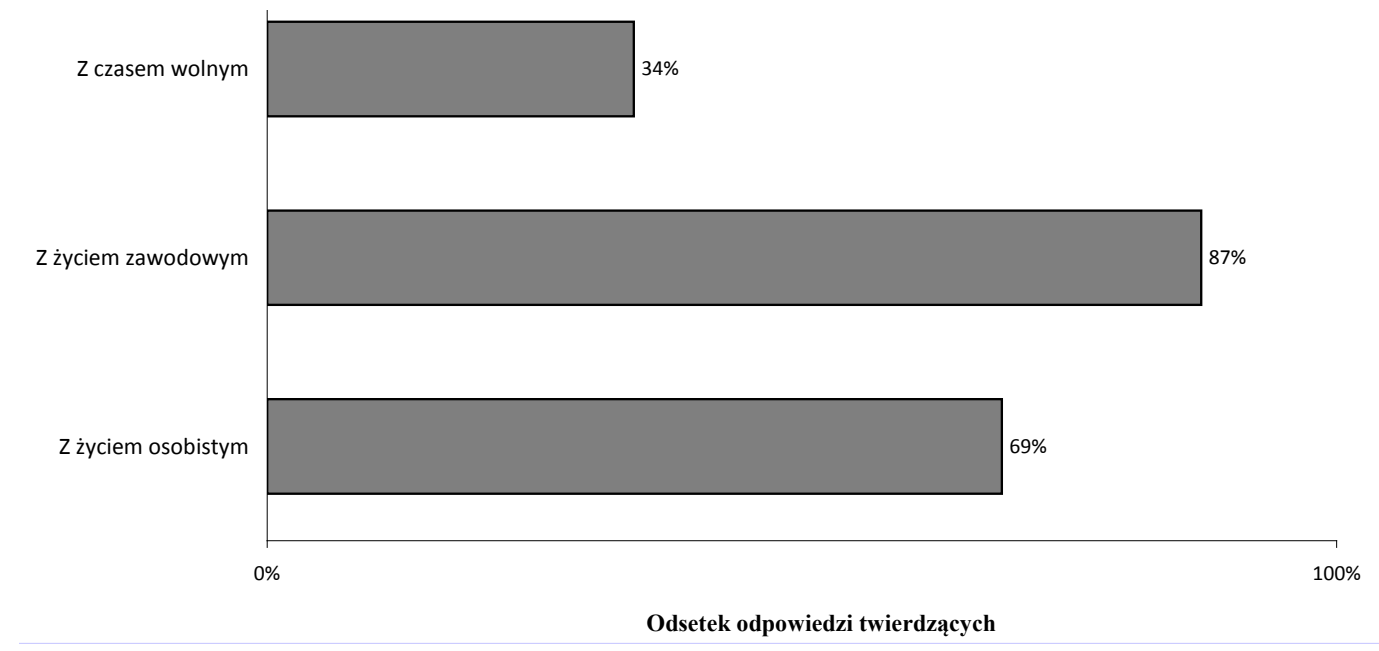

źródło: opracowanie własne

W celu sprawdzenia, czy odpowiedzi respondentów różniły się w zależności od pełnionej względem ucznia roli oraz typu instytucji edukacyjnej, przeprowadzono analizę log-liniową. Otrzymane wyniki wskazują na występowanie statystycznie istotnej zależności pomiędzy usytuowaniem roli i dostrzeganiem związku pomiędzy e t o s e m i życiem zawodowym $\chi^{2}(1, N=243)=5,15 ; p=0,023$. Odsetek nauczycieli dostrzegających związek etosu z życiem zawodowym (92\%) jest w sposób statystycznie istotny wyższy od odsetka rodziców (82\%).

Znacząco więcej nauczycieli (różnica wynosi 10\%) zauważa związek etosu z życiem zawodowym (rysunek 3). Opisane powyżej doświadczenia u tej grupy społecznej są dodatkowo uzupełniane przez bieżące sygnały związane z oczekiwaniami społecznymi. Każdy kontakt z uczniem czy jego rodzicem jest okazją do uzyskania informacji związanej z wymaganiami względem nauczyciela. Wykonując zawód związany z wychowaniem drugiego człowieka, nauczyciele nie tylko czują ciężar odpowiedzialności, ale również kreują swój wizerunek zgodnie z funkcjonującymi przekonaniami.

W wyniku przeprowadzonej analizy log-liniowej otrzymano również istotny statystycznie efekt interakcyjny pomiędzy usytuowaniem roli i wiekiem a dostrzeganiem związku pomiędzy etosem i życiem osobistym. Rysunek 4 prezentuje naturę efektu interakcji. W grupie rodziców w wieku średniej dorosłości odsetek osób uważających, że etos jest związany z życiem osobistym (77\%) jest wyższy niż w grupie rodziców w okresie wczesnej dorosłości $(56 \%), \chi^{2}(1, N=118)=5,23 ; p=0,022$. W przypadku nauczycieli, różnice pomiędzy obydwiema grupami wiekowymi są statystycznie nieistotne, $\chi^{2}(1, N=125)=0,74 ; p=0,390$.

Rysunek 3. Rozkład odpowiedzi na pytanie: „Z czym kojarzy się etos?”. Związek odpowiedzi $\mathrm{z}$ usytuowaniem roli respondenta 


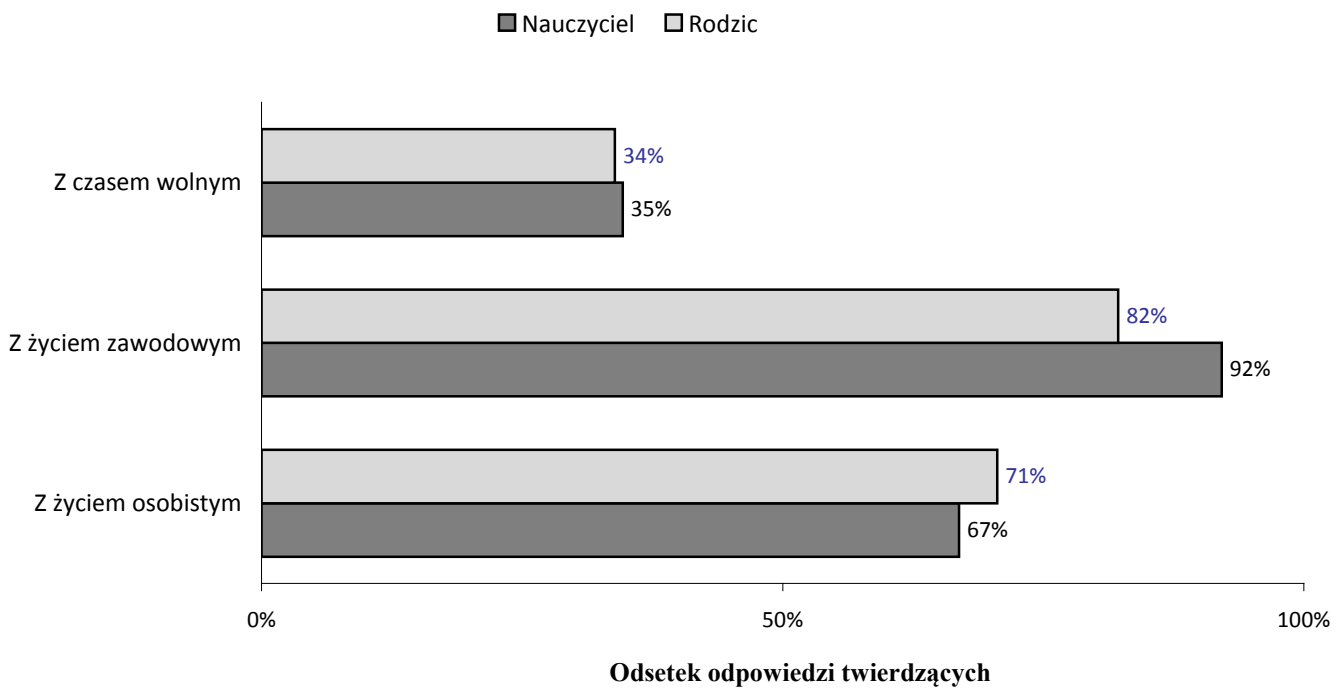

źródło: opracowanie własne

Rysunek 4. Związek etosu z życiem osobistym. Rozkład odpowiedzi w zależności od usytuowania roli respondenta względem dziecka i wieku

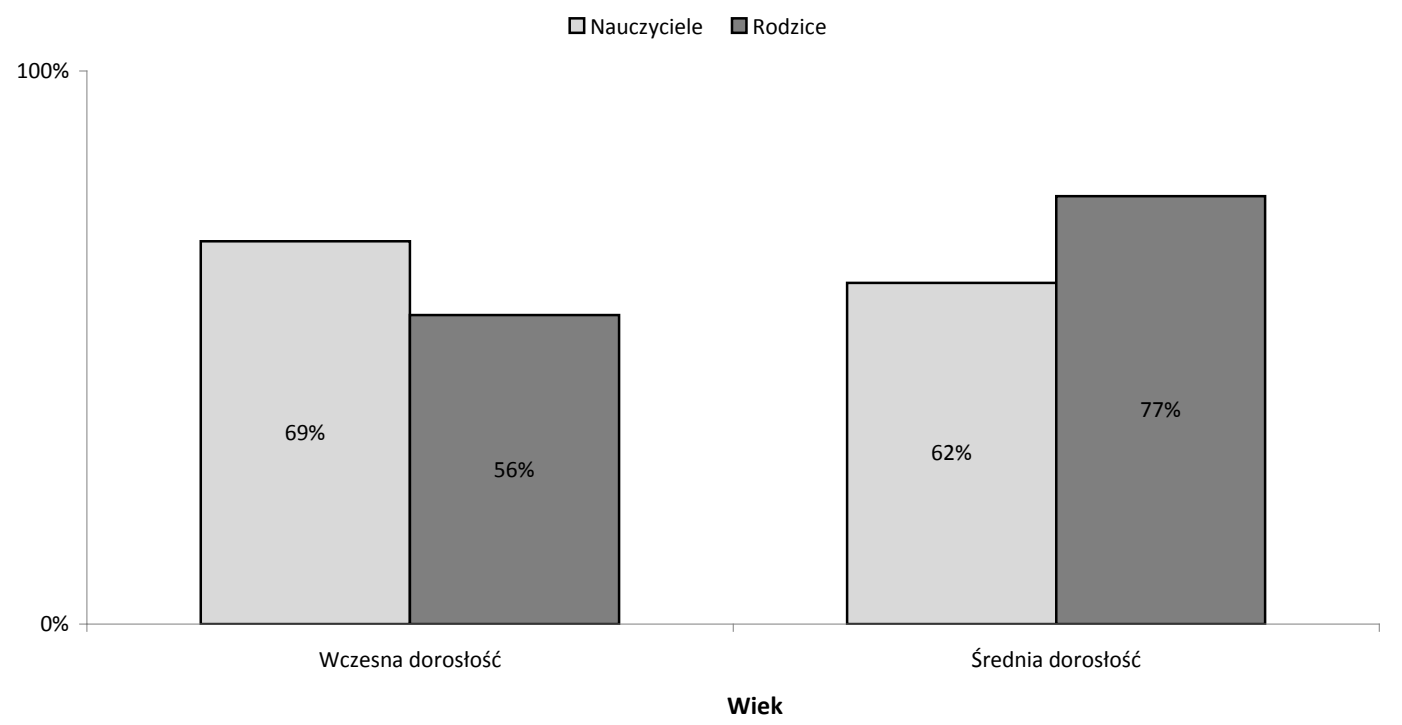

źródło: opracowanie własne

Z przeprowadzonej analizy wynika, iż starsi rodzice znacznie częściej wiążą zagadnienie etosu z życiem osobistym. Sytuacja taka może mieć miejsce chociażby dlatego, iż w przeszłości częściej postrzegano profesję nauczycielską w kategoriach misji społecznej, w związku z tym wymagano od jej przedstawicieli etycznej postawy obejmującej zarówno pracę, jak i sferę prywatną. Czy zatem wymagania społeczne względem nauczycieli rosną, maleją, a może po prostu ulegają zmianie? Podczas opisywanego badania respondenci pełniący obydwie role mieli okazję wypowiedzieć się również i na ten temat.

W przebadanej próbie 95\% wszystkich ankietowanych osób udzieliło twierdzącej odpowiedzi na pytanie: „Czy od czasów, kiedy Pani/Pan chodziła/ł do szkoły do chwili 
obecnej nastąpiły zmiany w oczekiwaniach społecznych wobec nauczycieli?”. Pozostałe 5\% badanych stwierdziło, że nic się w tej kwestii nie zmieniło.

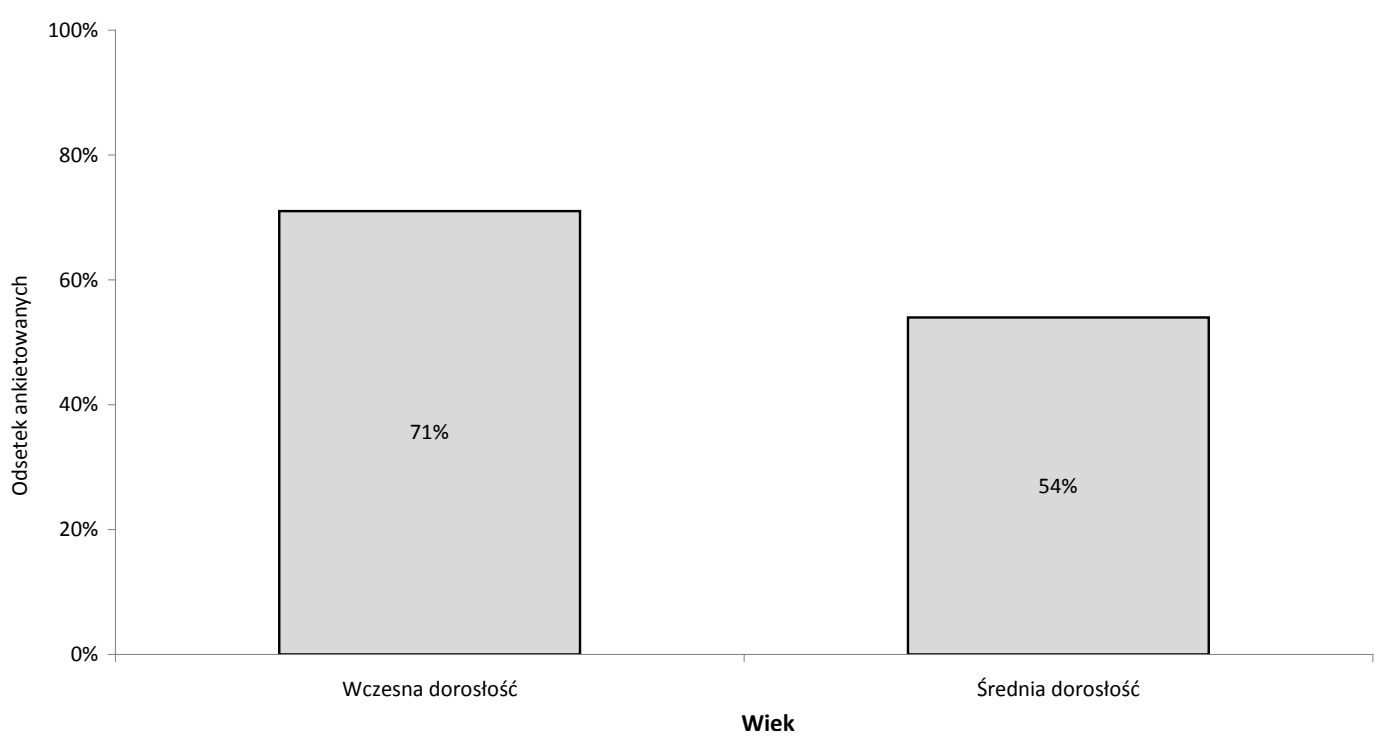

W celu sprawdzenia, czy percepcja zmian w oczekiwaniach społecznych wobec nauczycieli w poszczególnych podgrupach różni się od siebie, przeprowadzono testy współzależności zmiennych przy pomocy analizy log-liniowej i testu chi-kwadrat niezależności. Przedstawione w tabeli 2 wyniki wskazują na to, że w grupie nauczycieli odsetek osób dostrzegających zmiany w oczekiwaniach wobec nauczycieli (98\%) jest wyższy niż w grupie rodziców (93\%). Ponadto stwierdzono, iż odsetek kobiet udzielających twierdzącej odpowiedzi (96\%) jest wyższy niż odsetek mężczyzn (88\%). Obydwa zaobserwowane efekty są tendencjami statystycznymi (tabela 2).

Tabela 2. Związek usytuowania roli i typu instytucji edukacyjnej z percepcją terminu „etos” - wyniki analizy log-linowej

\begin{tabular}{lllll}
\hline Zmienne niezależne & $N$ & $D f$ & $\chi^{2}$ & $p$ \\
\hline Usytuowanie roli & 252 & 1 & 3,21 & 0,073 \\
Typ instytucji & 252 & 1 & 0,01 & 0,969 \\
Usytuowanie roli * typ instytucji & 252 & 1 & 0,01 & 0,906 \\
Wiek & 251 & 1 & 0,12 & 0,725 \\
Wiek $^{*}$ usytuowanie roli & 251 & 1 & 1,25 & 0,264 \\
Płeć & 254 & 1 & 3,14 & 0,076 \\
\hline
\end{tabular}

źródło: opracowanie własne

Przeprowadzona analiza wykazała również, że w grupie wiekowej wczesnej dorosłości odsetek osób uważających, że wymagania w stosunku do nauczyli wzrosły, jest wyższy niż w grupie średniej dorosłości (rysunek 5). Starsi respondenci oczekują od nauczycieli większego zaangażowania osobistego i rzadziej mówią o wzroście oczekiwań względem 
nauczycieli (rysunek 5). Najwidoczniej uważają pracę pedagogiczną za społecznie ważne zadanie, a samą grupę zawodową postrzegają jako zbiorowość zobowiązaną do dużej aktywności na rzecz uczniów.

Dotychczasowe rozważania dotyczyły wiedzy respondentów na temat pojęcia e t o s u. Uznano, iż zanim zostanie zbadany stosunek badanych do tego zagadnienia, należy sprawdzić, co wiedzą na jego temat. Okazało się, iż tylko niewielki procent ankietowanych nigdy nie słyszał o etosie i wyniki są niezależne od płci, wieku i roli pełnionej względem dziecka. Znacząco różni się natomiast postrzeganie oczekiwań społecznych względem nauczycieli. Ten wniosek wydaje się być ważny przy podejmowaniu dalszych rozważań, może być sygnałem, iż rodzice i pedagodzy nie są zgodni co do tego, jaka jest rola zawodowa nauczycieli. Rysunek 5. Rozkład odpowiedzi na pytanie: „Czy obecnie wymaga się od nauczycieli więcej niż kiedyś?” Związek opinii i wieku badanych

źródło: opracowanie własne

\section{Aktualność pojęcia etos}

W dalszej części badania zapytano respondentów o aktualność terminu. W przebadanej próbie $61 \%$ ankietowanych osób stwierdziło, że termin e t o s nadal funkcjonuje w świadomości społecznej. Pozostałe $39 \%$ badanych uważa etos za termin historyczny (rysunek 6).

Rysunek 6. Rozkład odpowiedzi na pytanie: „Jaka jest według Pani/Pana aktualność pojęcia etos?"

$\square$ Termin etos nadal funkcjonuje w świadomości społecznej

$\square$ Etos obecnie jest już jedynie terminem historycznym

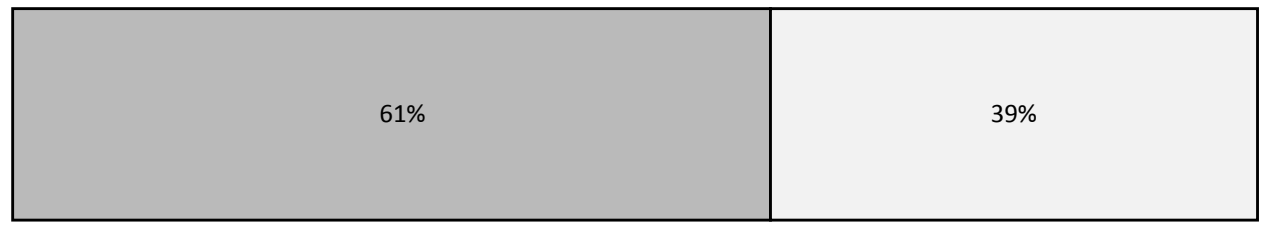

$0 \%$

źródło: opracowanie własne

$\mathrm{W}$ celu sprawdzenia, czy zmienne niezależne są związane $\mathrm{z}$ odpowiedziami respondentów w sposób statystycznie istotny, przeprowadzono testy współzależności zmiennych przy pomocy analizy log-liniowej i testu chi-kwadrat niezależności (tabela 3, rysunek 7). Przeprowadzone analizy nie wykazały istnienia zależności istotnych statystycznie. Oznacza to, że rozkłady odpowiedzi respondentów w poszczególnych porównywanych ze sobą podgrupach były do siebie zbliżone. 
Tabela 3. Testy zależności pomiędzy zmiennymi niezależnymi i oceną aktualności pojęcia etosu

\begin{tabular}{lllll}
\hline Zmienne niezależne & $N$ & $D f$ & $\chi^{2}$ & $p$ \\
\hline Usytuowanie roli & 252 & 1 & 1,82 & 0,177 \\
Typ instytucji & 252 & 1 & 1,67 & 0,196 \\
Usytuowanie roli ${ }^{*}$ typ instytucji & 252 & 1 & 0,40 & 0,525 \\
Wiek & 250 & 1 & 0,41 & 0,520 \\
Wiek * usytuowanie roli & 250 & 1 & 0,13 & 0,724 \\
Płeć & 253 & 1 & 0,98 & 0,328 \\
\hline
\end{tabular}

źródło: opracowanie własne

Rysunek 7. Rozkład odpowiedzi na pytanie: „Jaka jest według Pani/Pana aktualność pojęcia etos?", w zależności od usytuowania roli respondenta względem dziecka i instytucji edukacyjnej

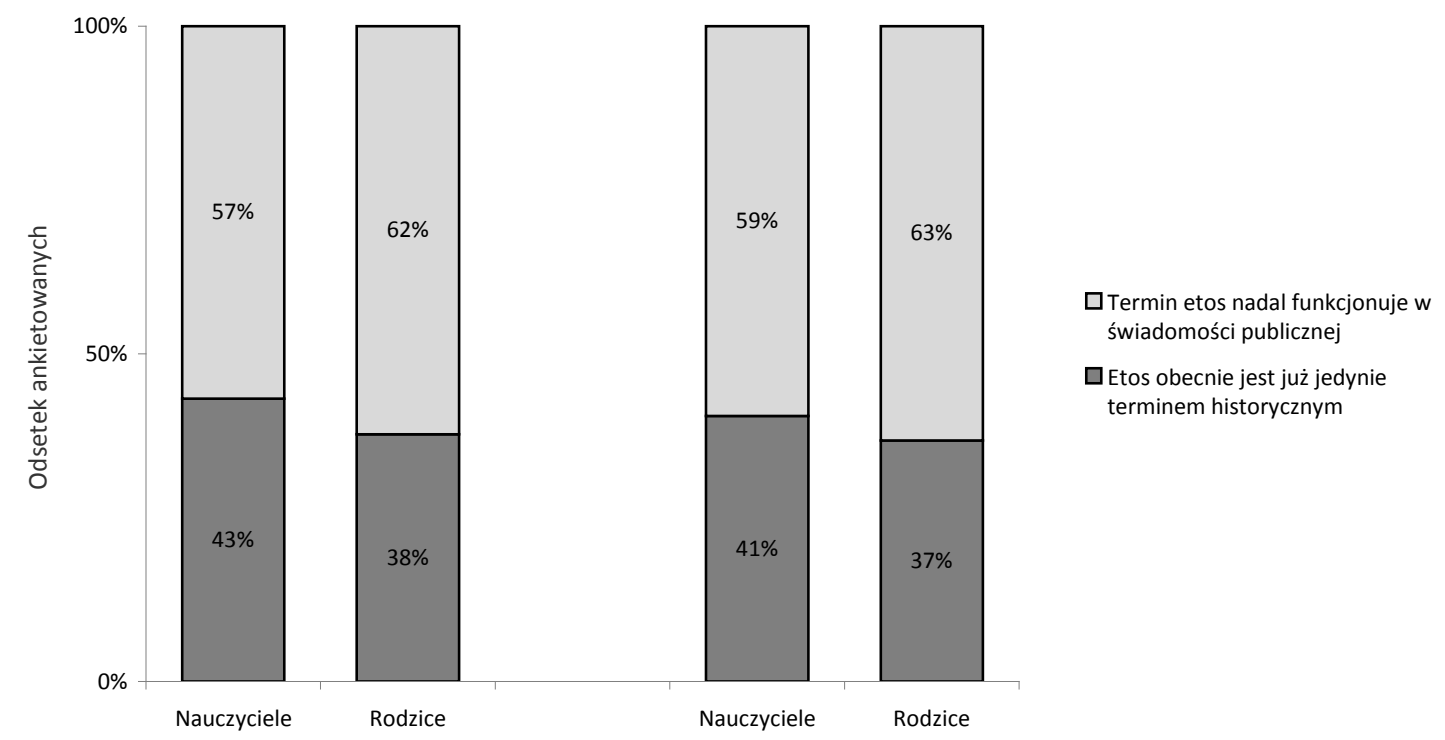

źródło: opracowanie własne

Prawie wszyscy respondenci, niezależnie od roli społecznej, znają pojęcie etosu, jednak tylko ich mniejsza część (39\%) uważa pojęcie za aktualne (rysunek 6). Wydawałoby się zatem, iż w pytaniu o znaczenie etosu mniej będzie odpowiedzi świadczących o jego wielkiej wadze. Jeśli jakaś kategoria pojęciowa wydaje się nieaktualna, raczej oczekuje się, iż dla oceniających nie ma ona wielkiego znaczenia. Badania nad etosem ujawniły zupełnie inną sytuację.

Dla większości respondentów (83\%) niezależnie od pełnionych ról, ich wieku i reprezentowanej placówki, etos jest bardzo ważny lub ważny (rysunek 8).

Rysunek 8. Rozkład odpowiedzi na pytanie: „Jak wysoko ocenia Pani/Pan wagę etosu w pracy nauczyciela?" 


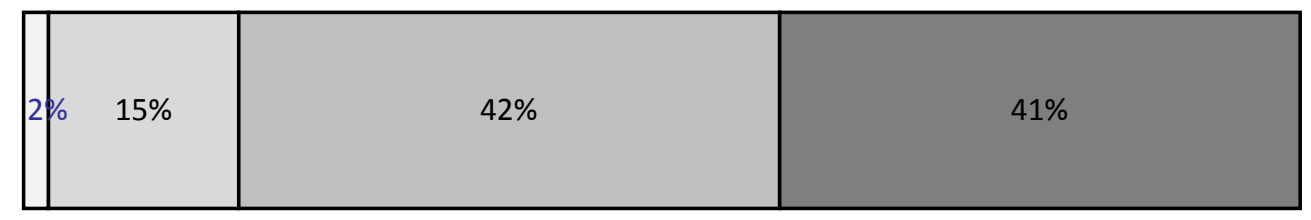

$0 \%$

Odsetek ankietowanych

$100 \%$

źródło: opracowanie własne

Jedynie $2 \%$ respondentów stwierdziło, iż etos jest mało ważny w pracy nauczyciela, $15 \%$ badanych uznaje go za średnio istotny. Ta analiza ukazuje interesującą zależność: badani uznali, iż kategoria pojęciowa, która jest obecnie niezbyt aktualna, ma dla nich duże znaczenie. W związku z tym można przypuszczać, iż etos w mniemaniu respondentów:

- jest średnio aktualnym pojęciem dla nich samych, mimo że jednocześnie uznają, iż powszechnie docenia się jego wagę,

- jest średnio aktualnym terminem w świadomości społecznej, ale dla nich samych jest ważny lub nawet bardzo ważny.

Zróżnicowanie odpowiedzi, rozdźwięk między znajomością, aktualnością a wagą etosu ukazuje, iż mimo niejednoznaczności poglądów respondentów etos jest fenomenem nadal żywo obecnym w powszechnej opinii. Co może mieć wpływ na takie zróżnicowanie wyników? Wydaje się, że różnica doświadczeń w życiu osób w różnym wieku i pełniących rozmaite role oraz wielość zadań w biografii każdej pojedynczej jednostki może mieć związek z asymetrycznością wyników. Respondenci prawdopodobnie spotkali się z pojęciem etosu w szkole czy też w rodzinie w rozmowach ze starszym pokoleniem. Ich poglądy i stosunek do tego terminu mogły zmieniać się zależnie od pełnionych ról. Zapewne inaczej widzi się nauczyciela, gdy samemu jest się uczniem, a czego innego oczekuje się od niego, kiedy człowiek zostaje rodzicem i nauczycielska rola zawodowa jest spełniana wobec jego dzieci. Do tego dochodzą jeszcze doświadczenia osób, które same zostały nauczycielami. Bywa, iż między dwoma lub trzema obrazami tej samej roli społecznej w doświadczeniu jednej osoby nie ma powiązania. Obraz ten z czasem ulega zmianie, a wszystkie zróżnicowania nie są w pełni uświadomione i brakuje im uporządkowania. Prawdopodobnie również etos nie jest tematem, który respondenci rozważają na co dzień. Bieżący kontakt ze szkołą zapewne rzadko jest wiązany z kwestią postaw czy wartości nauczycieli. Dzieje się tak raczej jedynie w przypadku jakiś szczególnych sytuacji - bardzo pozytywnych lub wyjątkowo negatywnych doświadczeń związanych z konkretnym nauczycielem. Ankieta wypełniana przy okazji opisywanych badań mogła wywołać szereg refleksji, które nie były obecne w świadomości respondentów podczas bieżących kontaktów ze szkołą. 


\section{Waga etosu}

Dla sprawdzenia, czy ocena wagi etosu różni się w zależności od usytuowania roli respondenta względem ucznia i typu instytucji edukacyjnej przeprowadzono serię testów rangowych U Manna-Whitneya. W pierwszej analizie dokonano porównania ocen pomiędzy grupą nauczycieli i rodziców. Przeprowadzona analiza wykazała, że rodzice wyżej oceniają wagę etosu w pracy nauczyciela $($ Mrang $1=138,27)$ niż nauczyciele $($ Mrang2 $=118,43), U=$ $6855 ; p=0,020$. Na poniższym rysunku przedstawiono rozkłady odpowiedzi na pytanie, uwzględniając podział ze względu na usytuowanie roli względem ucznia.

Rysunek 9. Rozkład odpowiedzi na pytanie: „Jak wysoko ocenia Pani/Pan wagę etosu w pracy nauczyciela?”, w zależności od usytuowania roli względem ucznia

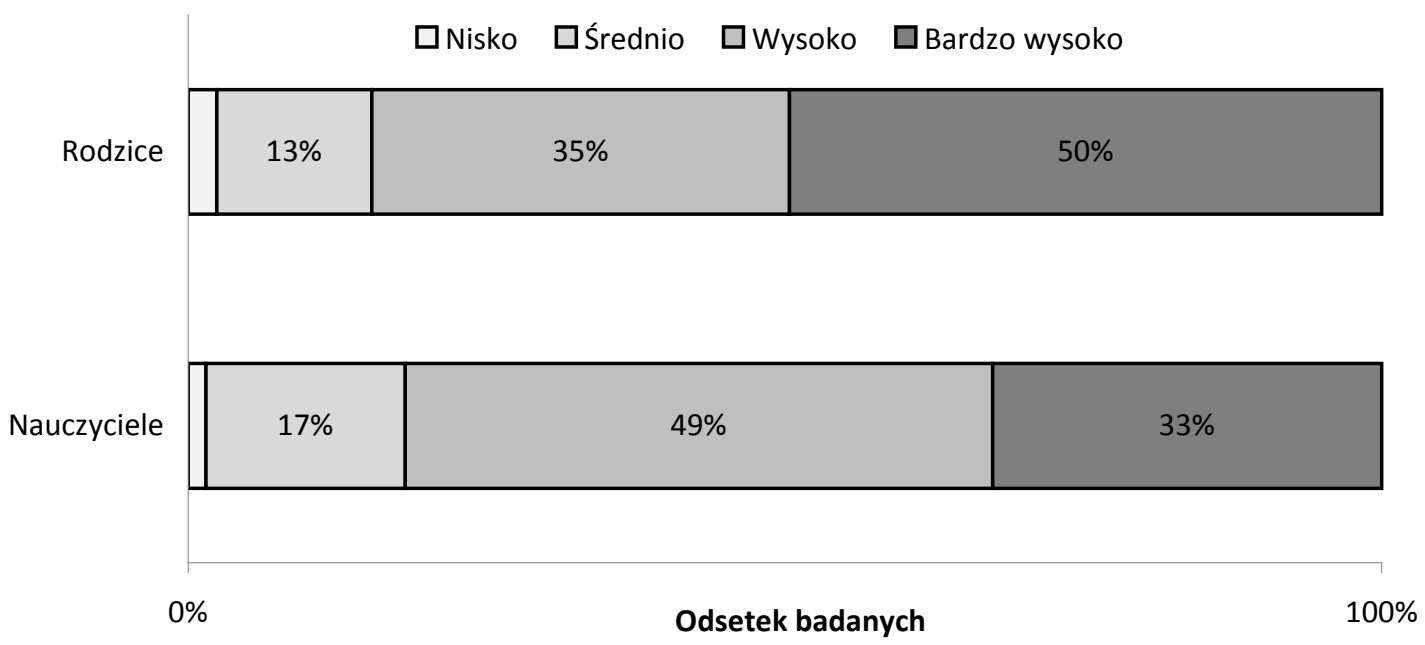

źródło: opracowanie własne

Badanie wykazało, iż znacząco większy odsetek rodziców uważa etos za bardzo ważny element pracy nauczyciela. Potwierdzają to również wcześniej zaprezentowane wyniki badań. Oczekiwania społeczne względem nauczycieli są duże. Mimo że współcześnie nauczycielski profesjonalizm jest wiązany przez społeczeństwo raczej z przekazem wiedzy i umiejętności pod kątem przyszłego przygotowania do zawodu, oczekiwania natury etycznej nadal zajmują ważne miejsce w myśleniu o powinnościach nauczyciela. Sami nauczyciele sądzą, iż etos jest istotnym czynnikiem ich zawodu. Gdyby porównać odpowiedzi rodziców i pedagogów w połączonych grupach wysokiej i bardzo wysokiej wagi etosu, wyniki byłyby zbliżone ( $85 \%$ rodziców i $82 \%$ nauczycieli uważa etos za ważny lub bardzo ważny). Niemniej jednak to większy odsetek rodziców niż nauczycieli uznał etos za bardzo istotny element nauczycielskiej pracy.

W związku z powyższym zapytano o to, jaki element nauczycielskiej profesji jest ważniejszy niż etos zawodowy. Zadano to dodatkowe pytanie to po, żeby dogłębnie poznać opinie respondentów i uszczegółowić ich odpowiedzi dotyczące wagi badanego zagadnienia. Sam fakt zadeklarowania przywiązywania dużego znaczenia do etosu nauczycielskiego nie pokazuje, jakie inne elementy tej profesji są dla respondentów istotne. Dopiero takie spojrzenie na sprawę pozwoli usytuować etos pośród pozostałych priorytetów respondentów. 
Rysunek 11. Rozkład odpowiedzi na pytanie: „Czy któryś z elementów pracy nauczyciela jest według Pani/ Pana ważniejszy niż etos?”

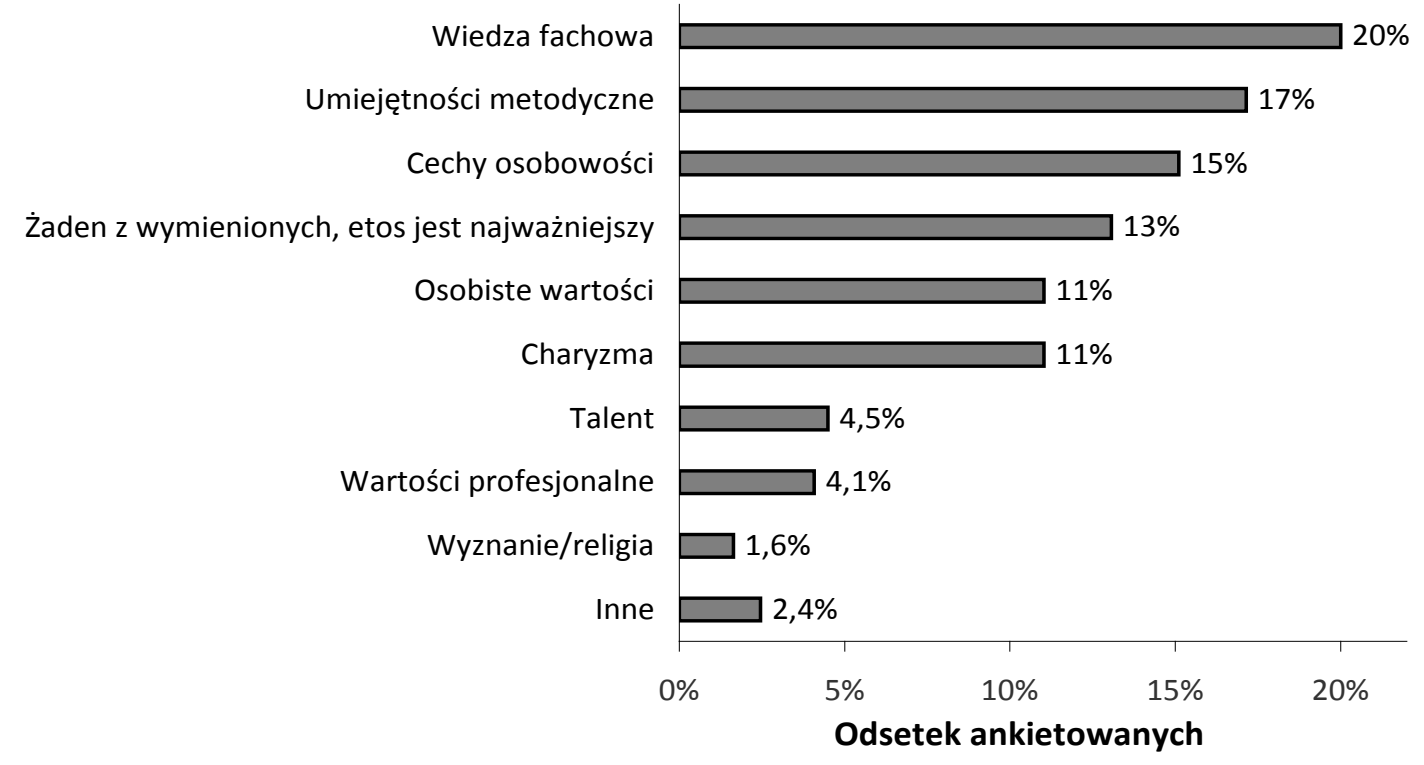

źródło: opracowanie własne

Najważniejsza w pracy nauczyciela dla przedstawicieli wszystkich grup okazała się wi e d z a fachowa. Wynik ten wydaje się być potwierdzeniem współczesnych obiegowych opinii na temat nauczycielskiego profesjonalizmu i w pewnym sensie potwierdza oczekiwania społeczne, o których była mowa wcześniej. Oczekując od nauczycieli przygotowania uczniów do zaistnienia na rynku pracy, wymaga się od nich przede wszystkim przekazu fachowej wiedzy. Podobnie rzecz ma się z umiejętnościami metodycznymi. Sposób przekazywania wiedzy wiąże się znacząco z efektywnością pracy nauczyciela. Wszystkim dorosłym podmiotom edukacji zależy na satysfakcjonujących wynikach procesu kształcenia coraz częściej mierzonych za pomocą liczbowo interpretowalnych testów. Cechy osobowości wykazują niewątpliwy związek z atrakcyjnością interpersonalną, o której była mowa w rozdziale dotyczącym grup społecznych i mają niewątpliwy wpływ na skuteczność nauczycielskiego oddziaływania. Trzynaście procent odpowiedzi wskazywało na największe znaczenie etosu pośród innych elementów nauczycielskiej profesji. To sytuuje etos na dość wysokim, czwartym miejscu na liście priorytetowych determinantów profesjonalizmu nauczyciela. Można przypuszczać, iż sam temat badania mógł sprowokować ten wynik, ale niekoniecznie taka sytuacja miała miejsce w przypadku wszystkich respondentów. Sama ankieta mogła wywołać wiele refleksji związanych z etyczną stroną pracy pedagogicznej i w efekcie tego namysłu doprowadzić respondentów do przekonania o dużym znaczeniu etosu.

W celu sprawdzenia, czy odsetki badanych wskazujących poszczególne odpowiedzi różnią się w zależności od usytuowania roli względem ucznia i typu instytucji edukacyjnej, wykonano modelowanie logarytmiczno-liniowe. Dla każdej kategorii odpowiedzi została przeprowadzona jedna analiza log-liniowa.

W wyniku przeprowadzonych analiz stwierdzono, że odsetek osób uważających, że w pracy nauczyciela c e c h y o s o b o w o ś c i są ważniejsze niż etos, jest w sposób istotny 
statystycznie wyższy w grupie nauczycieli (22\%) niż w grupie rodziców $(7,5 \%), \chi^{2}(1, N=245)$ $=9,60 ; p=0,002$. W przypadku c h a r y z m y odsetek odpowiedzi był wynikiem łącznego wpływu usytuowania roli wobec ucznia i typu instytucji, $\chi^{2}(1, N=243)=3,74 ; p=0,053$ (tendencja statystyczna). Na rysunku 12 przedstawiono odsetki osób w poszczególnych podgrupach uważających, że $\mathrm{w}$ pracy nauczyciela $\mathrm{c} h$ a r y $\mathrm{z} \mathrm{m}$ a ma większe znaczenie niż etos. $Z$ danych przedstawionych na wykresie wynika, iż wśród rodziców, których dziecko jest uczniem szkoły podstawowej, odsetek osób uważających, że charyzma jest ważniejsza niż etos, okazał się wyraźnie wyższy niż w pozostałych podgrupach.

Rysunek 12. Odsetek ankietowanych uważających, że ch a r y z m a ma w pracy nauczyciela większe znaczenie niż etos, w zależności od usytuowania roli respondenta względem dziecka i instytucji edukacyjnej

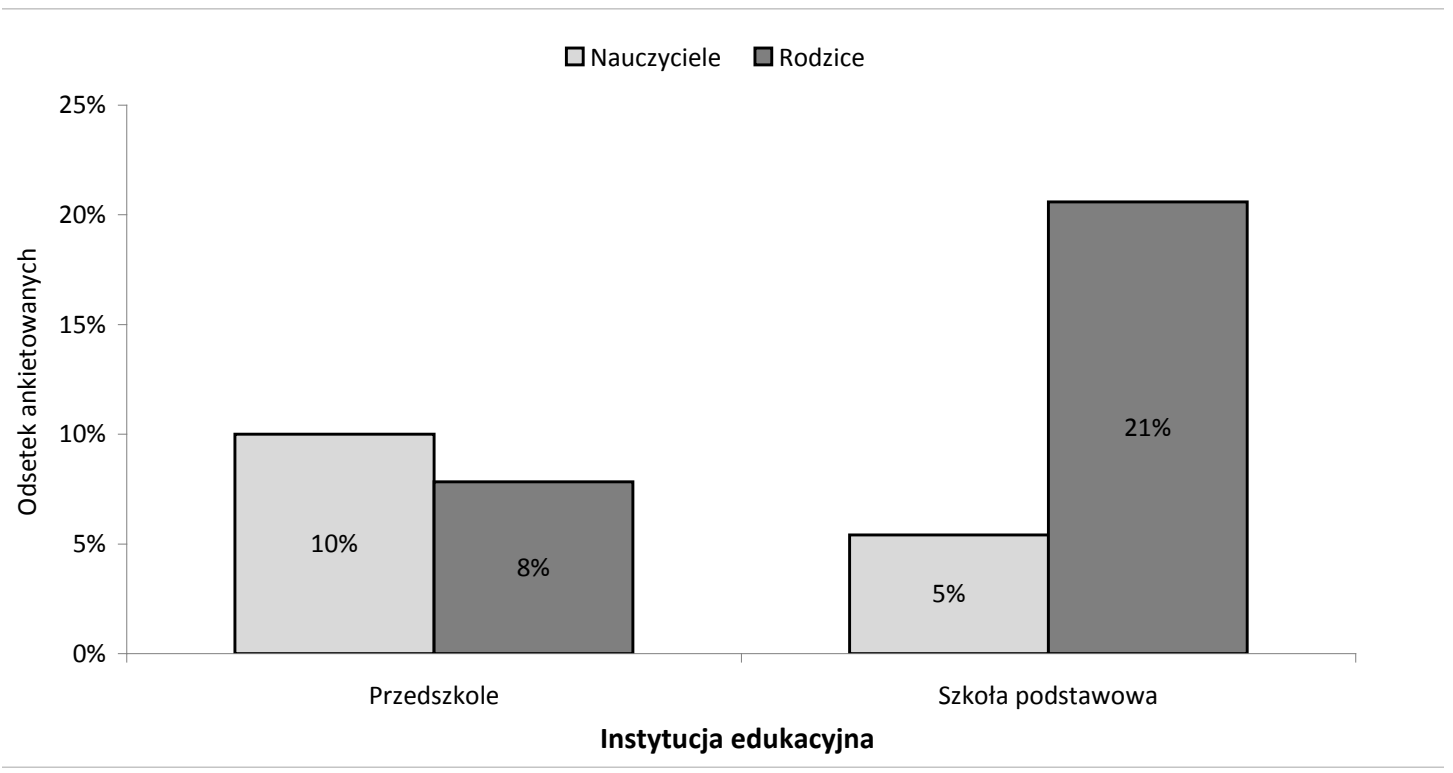

źródło: opracowanie własne

Przyczyny takiego stanu rzeczy można dopatrywać się w wieku dziecka, którego rodzice odpowiadali na pytanie. Czego innego oczekuje się od instytucji dydaktyczno-wychowawczej, gdy potrzeby małego dziecka sytuują się w obrębie wymagań opiekuńczych, a edukacja postrzegana jest jako czynność odbywająca się niejako przy okazji innych działań (na przykład zabawy). Młody uczestnik edukacji wczesnoszkolnej i jego rodzice mają również inne potrzeby i oczekiwania niż środowisko rodzinne nastolatka. O ile rodzice małego dziecka zapewne wskazaliby umiejętności opiekuńczo-wychowawcze jako priorytetowe w działaniach nauczyciela, ważniejsze dla opiekunów starszych uczniów mogłyby się okazać elementy związane z przekazem wiedzy. Powszechnie wiadomo, że na kolejnych stopniach edukacji naturalna ciekawość dziecka może ulegać zmniejszeniu, z czego doskonale zdają sobie sprawę rodzice starszych uczniów. Z tego względu prawdopodobnie wskazywali charyzmę jako istotną cechę nauczyciela, która może zachęcać dzieci do nauki i czynić proces uczenia się atrakcyjniejszym. 


\section{Wzór nauczyciela}

Wielu respondentom zagadnienie etosu kojarzy się ze wzorcowym systemem wartości lub z niedoścignionym ideałem. Ta wiedza potoczna nie jest wcale daleka od definicji etosu pochodzących z literatury naukowej (Meibaum 1979, Szawiel 1982, Chrobak 1992). Na kolejnym etapie badań zapytano ankietowanych o to, czy spotkali nauczyciela pozytywnie świadczącego o etosie swojej grupy zawodowej. Wcześniejsze odpowiedzi respondentów, mimo że istotne dla całości badań, nie pokazałyby w wystarczający sposób, jaki jest udział osobistego doświadczenia w ich poglądach na temat etosu. Ujawniły wiedzę i stosunek ankietowanych do badanej kategorii pojęciowej. Odpowiedź na pytanie o istotną osobę reprezentującą opisywany fenomen potwierdza wiarygodność wcześniej uzyskanych danych. Aż $87 \%$ badanych stwierdziło, że spotkało w życiu nauczyciela, który swoją osobą reprezentował nauczycielski etos zawodowy (rysunek 13). Ten odsetek mówi o adekwatności opinii będących rezultatem nie tylko wiedzy, ale i doświadczenia respondentów. Wynik powyższy w pewnym sensie potwierdza również aktualność pojęcia.

Rysunek 13. Rozkład odpowiedzi na pytanie: „Czy spotkała/ł Pani/Pan w nauczyciela, który swoją postawą pozytywnie świadczył o etosie własnej grupy zawodowej?”

$\square$ Tak, spotkałem $\quad \square$ Nie spotkałem

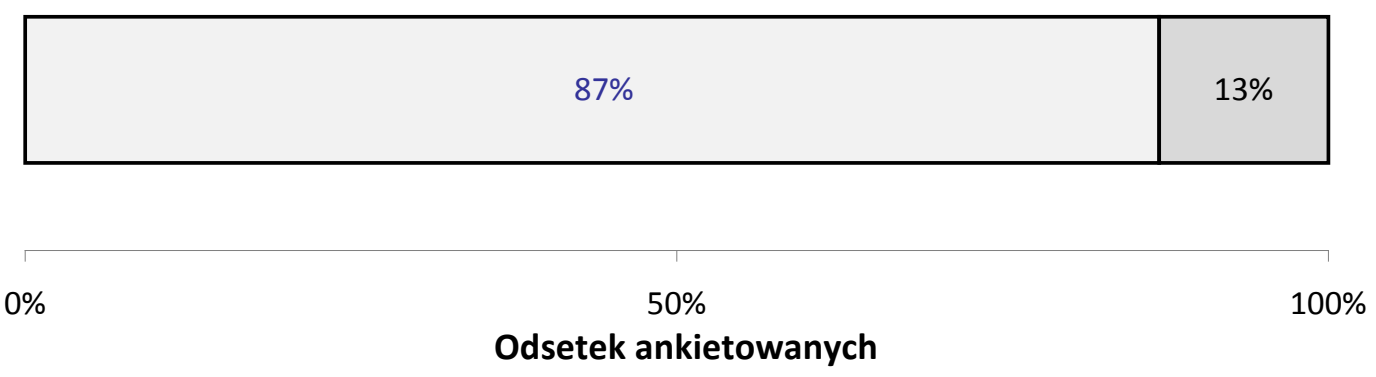

źródło: opracowanie własne

Aby dowiedzieć się, czy odpowiedzi ankietowanych różnią się w sposób istotny statystycznie w zależności od roli pełnionej względem ucznia, typu instytucji edukacyjnej, wieku i płci, przeprowadzono testy współzależności. Analizy te nie wykazały istnienia statystycznie istotnych związków pomiędzy zmiennymi niezależnymi i odpowiedziami respondentów (tabela 4). Odsetki osób, które w swoim życiu spotkały nauczyciela, który pozytywnie świadczył o etosie, były we wszystkich badanych podgrupach zbliżone.

Tabela 4. Testy zależności pomiędzy zmiennymi niezależnymi i odpowiedzią na pytanie: „Czy udało się Pani/Panu spotkać w swoim życiu nauczyciela, który pozytywnie świadczył o etosie własnej grupy zawodowej?”

\begin{tabular}{lllll}
\hline Zmienne niezależne & $\mathrm{N}$ & $\mathrm{df}$ & $\chi^{2}$ & $\mathrm{p}$ \\
\hline Usytuowanie roli & 249 & 1 & 1,82 & 0,177 \\
Typ instytucji & 249 & 1 & 1,67 & 0,196
\end{tabular}




\begin{tabular}{lllll} 
Usytuowanie roli`typ instytucji & 249 & 1 & 0,40 & 0,525 \\
Wiek & 248 & 1 & 0,24 & 0,621 \\
Wiek $^{\star}$ usytuowanie roli & 248 & 1 & 0,04 & 0,842 \\
Płeć & 251 & 1 & 0,19 & 0,663 \\
\hline
\end{tabular}

źródło: opracowanie własne

O ile poprzednia analiza mogła napawać optymizmem dotyczącym wizerunku nauczyciela w społeczeństwie, to odpowiedź na kolejne pytanie nie jest już tak podnosząca na duchu. Respondenci powiedzieli, iż współcześnie można spotkać nauczycieli pozytywnie świadczących o etosie swojej grupy zawodowej (92\% odpowiedzi), ale duży odsetek badanych (66\%) uznał, że nie ma już zbyt wielu takich nauczycieli (rysunek 14).

Rysunek 14. Rozkład odpowiedzi na pytanie: „Czy obecnie jest wielu nauczycieli świadczących swoją postawą o etosie grupy zawodowej, do której należy?”

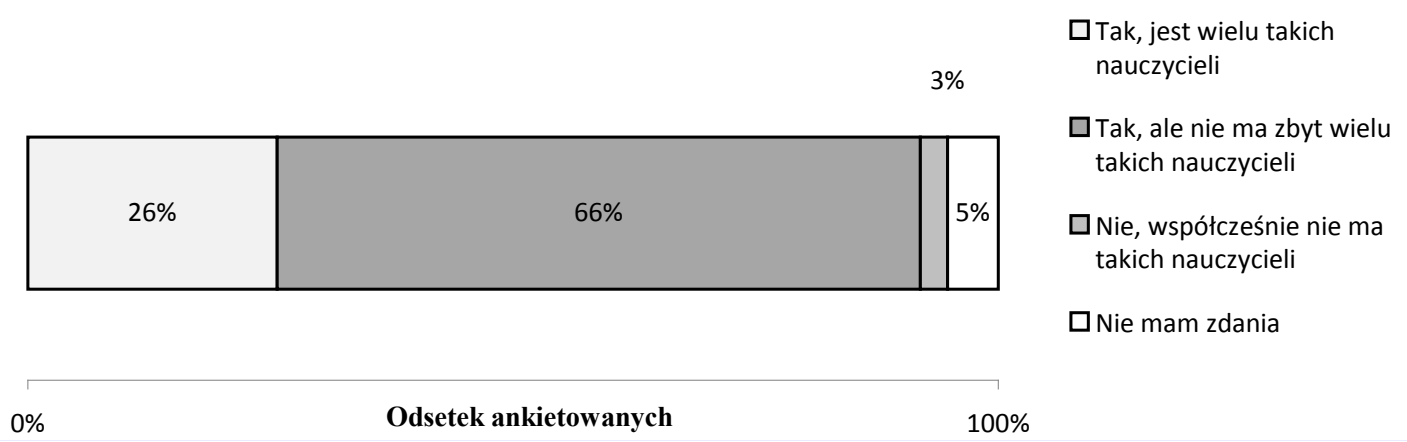

źródło: opracowanie własne

Interesującym może wydawać się fakt braku zróżnicowania odpowiedzi ze względu na rolę, wiek i instytucję reprezentowaną przez respondenta, o czym przekonują wyniki przeprowadzonej analizy log-liniowej i testu chi-kwadrat niezależności (tabela 5).

Tabela 5. Ocena częstości występowania odpowiedzi dotyczących nauczycieli świadczących swoją postawą o etosie grupy zawodowej - wyniki analizy współzależności

\begin{tabular}{lllll}
\hline Zmienne niezależne & $\mathrm{N}$ & $\mathrm{df}$ & $\chi^{2}$ & $\mathrm{p}$ \\
\hline Usytuowanie roli & 247 & 3 & 2,50 & 0,475 \\
Typ instytucji & 247 & 3 & 2,61 & 0,456 \\
Usytuowanie rolityp instytucji & 247 & 3 & 1,73 & 0,631 \\
Wiek & 246 & 3 & 0,97 & 0,809 \\
Wiek ${ }^{*}$ usytuowanie roli & 246 & 3 & 3,88 & 0,275
\end{tabular}




\begin{tabular}{lllll}
\hline Zmienne niezależne & $\mathrm{N}$ & $\mathrm{df}$ & $\chi^{2}$ & $\mathrm{p}$ \\
\hline Płeć & 249 & 3 & 7,72 & 0,052 \\
\hline
\end{tabular}

źródło: opracowanie własne

Jedynie w przypadku płci różnice pomiędzy porównywanymi grupami są bliskie istotności statystycznej $(\mathrm{p}=0,052)$. W grupie kobiet, odpowiedzi: „Tak, jest wielu takich nauczycieli” oraz „Tak, ale nie ma zbyt wielu takich nauczycieli” występowały częściej niż w grupie mężczyzn. Szczegółowy rozkład odpowiedzi w obydwu porównywanych grupach przedstawiono na rysunku 15.

Rysunek 15. Rozkład odpowiedzi na pytanie: „Czy obecnie można spotkać nauczycieli pozytywnie świadczących o etosie własnej grupy zawodowej?”, w zależności od płci

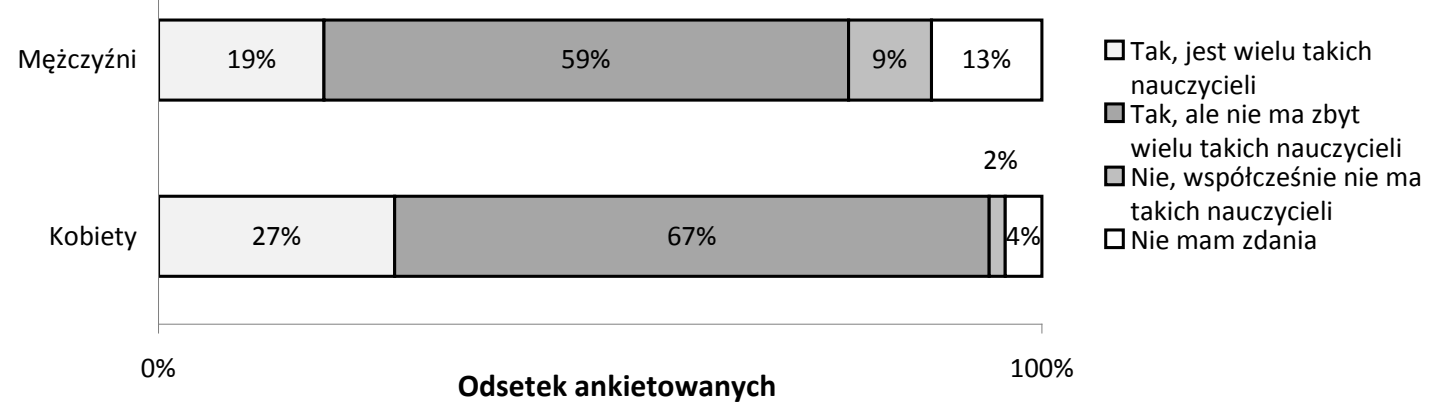

źródło: opracowanie własne

Wydaje się, iż społeczna percepcja roli zawodowej nauczyciela współcześnie nie jest zbyt pozytywna. Sześćdziesiąt sześć procent badanych stwierdziło, że nie ma obecnie zbyt wielu nauczycieli reprezentujących wzorcowy etos swojej grupy zawodowej. Biorąc pod uwagę, iż kompetencje etyczne stanowią istotny element nauczycielskiego profesjonalizmu, wyniki te nie napawają optymizmem.

\section{Wnioski końcowe}

Przeprowadzone badania wykazały bardzo wiele interesujących prawidłowości. Pojęcie e t o s jest znanym, a nawet powszechnie znanym terminem (93-100\% respondentów zależnie od roli i płci znało to pojęcie). Mimo to $39 \%$ procent respondentów sądzi, iż etos jest już terminem historycznym. Zatem dlaczego aż 83\% uważa etos za ważny lub nawet bardzo ważny w pracy nauczyciela? Czy te odpowiedzi nie wykluczają się? Można domniemywać, iż nadal istnieje wymaganie społeczne, aby nauczyciel był nie tylko profesjonalnym edukatorem. Wydaje się, iż występuje powszechna tęsknota za wychowawcą kładącym duży nacisk na kwestie etyczne nie tylko w wychowaniu młodzieży, lecz również we własnym postępowaniu. To domniemanie potwierdza również odpowiedź na inne pytanie, przy okazji którego 68\% respondentów uznało, iż obecnie nie ma zbyt wielu nauczycieli dbających o pozytywny etos swojej grupy zawodowej. Czy powyższe wyniki mogą powodować negatywizm w myśleniu o pracy współczesnych nauczycieli? Bardziej niż do pesymizmu należy skłaniać się w kierunku refleksji. Nadzieję może przynieść fakt spotkania w życiu 
nauczyciela - wzoru do naśladowania, który zadeklarowało aż $87 \%$ badanych. Potwierdza to, iż wielu respondentów miało szansę poznać nauczyciela, który był dla nich autorytetem.

Przedstawiając wnioski końcowe, zasadnym wydaje się również zwrócić uwagę na ich zróżnicowanie ze względu na badane zmienne niezależne takie jak wiek, płeć czy też rola pełniona przez respondenta w placówce edukacyjnej. Znacznie większa liczba nauczycieli niż rodziców dostrzegła związek etosu z życiem zawodowym (różnica wyniosła 10\%). Natomiast to rodzice częściej wskazywali na aktualność pojęcia etosu niż nauczyciele przy czym różnica ta była znacznie niższa ( $5 \% \mathrm{w}$ przypadku podmiotów związanych z przedszkolem; $4 \%$ - jeśli chodzi o rodziców i nauczycieli szkolnych). Oznaczałoby to, iż według znacznie większej liczby nauczycieli kwestia etosu powinna być zawężona jedynie do dziedziny życia zawodowego i współcześnie jest już mniej aktualna. Rodzice dzieci uważają, że nauczycielski etos winien mieć związek z życiem osobistym nauczyciela i że jest on nadal pojęciem aktualnym.

Jeśli chodzi o zmienną wieku, więcej osób młodszych (71\%) uważa, że obecnie wymagania względem nauczycieli wzrosły. Można domniemywać, iż ma to związek z pewnymi zjawiskami społecznymi związanymi ze zmianami w sposobie wychowania dzieci i młodzieży, ze zmniejszeniem się dystansu dorosłych i młodych oraz złagodzeniem poziomu oczekiwań względem osób młodych. Oceniają oni stawiane wymagania wyżej niż osoby starsze, odczuwając znaczniej ich ciężar.

Ponadto dostrzeżono w niektórych obszarach również zróżnicowanie odpowiedzi ze względu na płeć respondenta. Kobiety częściej stwierdzały, iż obecnie można spotkać wielu nauczycieli pozytywnie świadczących o etosie swojej grupy zawodowej. Różnica pomiędzy grupą badanych kobiet i mężczyzn wyniosła $8 \%$. Wydaje się, iż może mieć ona związek z większym znaczeniem wzorca osobowego w postaci konkretnego nauczyciela i silniejszym utożsamianiem się z nim niż w przypadku mężczyzn. Można domniemywać, iż częstotliwość spotkania dobrego nauczyciela w przypadku obydwu płci może być podobna, jednak fakt ten może mieć większe znaczenie dla kobiet niż dla mężczyzn.

Od zawsze do oceny pracy przedstawicieli zawodów związanych z szeroko pojętą służbą człowiekowi stosowano zupełnie inne kryteria niż w przypadku pozostałych profesji. $Z$ jednej strony media pełne są treści i obrazów zachęcających do życia skupionego na doraźnych, osobistych przyjemnościach. Ludzi, którzy nie podążają za tym trendem, uważa się za zapóźnionych i niegodnych uwagi. Z drugiej jednak strony obecna jest dyskusja społeczna o sytuacji w oświacie, zwiększają się wymagania względem zawodu nauczyciela. Rosnące oczekiwania wobec pedagogów początkowo skupiały się głównie wokół ich kwalifikacji. Wraz z rozwojem psychologii i rozumienia wpływu kompetencji osobistych na jakość pracy pedagogicznej wraca jak bumerang pytanie: czym jest to coś, co wyróżnia d obre g o n a u c z y c i ela? W badaniach opisanych w niniejszym artykule podjęto próbę wykazania, że tym istotnym elementem nauczycielskiej profesji jest w opinii rodziców i samych nauczycieli etos nauczycielski. Wydaje się, że nie tylko przekaz wiedzy związanej z zagadnieniami etycznymi jest ważny dla dorosłych związanych z edukacją dzieci i młodzieży. Zauważają oni wagę osobistej postawy nauczycieli. Znają pojęcie etosu i uważają je za istotny element nauczycielskiej profesji. Tym samym wielu ludzi w swoich doświadczeniach odnajduje praktyczny wzór i w pewnym sensie dowód na to, że nadal liczni przedstawiciele nauczycielskiej profesji nie tylko uczą jak żyć, ale sami żyją tak, jak uczą. 


\section{Bibliografia}

Czapiński J., Panek T. (2009). Diagnoza społeczna 2009. Warunki i jakość życia Polaków. Warszawa: Rada Monitoringu Społecznego.

Czarnowski S. (1958). Kultura. Warszawa: Państwowe Wydawnictwo Naukowe.

Klepajczuk B. (1995). Etos pracy w przededniu transformacji systemu społecznego. Szczecin: Wydawnictwo Naukowe Uniwersytetu Szczecińskiego.

Lalak D., Pilch T. (red.). (1999). Elementarne pojęcia pedagogiki społecznej i pracy socjalnej. Warszawa: Wydawnictwo Akademickie Żak.

Legowicz L. (1984). Życie dla życia. Warszawa: Państwowe Wydawnictwo „Wiedza Powszechna".

Meibaum B. (1979). Kategoria wzoru osobowego. W: Michalik M. (red.). Wartości a sposób życia. Wrocław: Wydawnictwo Polskiej Akademii Nauk.

Ossowska M. (1956). Moralność mieszczańska. Łódź: Zakład im. Ossolińskich.

Siciński A. (1976). Styl życia - problemy pojęciowe i teoretyczne. W: Siciński A. (red.). Styl $\dot{z} y c i a$. Warszawa: Państwowe Wydawnictwo Naukowe.

Scheler M. (2008). Resentyment a moralność. Warszawa: Aletheia.

Znamierowski Cz. (1964). Rozważania wstępne do nauki o moralności i prawie. Warszawa: Państwowe Wydawnictwo Naukowe.

\section{ETHOS OF THE CONTEMPORARY TEACHER IN THE OPINION OF TEACHERS AND PARENTS}

Abstract: The problem of teachers' ethos is still a very important issue which is not likely to go down into the background of the process of education and upbringing. Even if the concept of ethos is heard less and is associated rather with the belles-lettres, it does not mean it does not exist. The term itself is sometimes replaced by other terms, but it finds its place in literature and educational practice as indisputable and invariably present educational role of the school.

Key words: ethos, ethics of teaching, teacher, teaching profession, upbringing

Joanna Pękala - magister, doktorantka Wydziału Pedagogicznego Uniwersytetu Warszawskiego. Praktyk nauczania wczesnoszkolnego i przedszkolnego. Zainteresowania badawcze: pedeutologia, etyka nauczycielskiej profesji. Przygotowuje rozprawę doktorską na temat etosu współczesnego nauczyciela. Adres e-mail: joanna_sl@poczta.onet.pl 